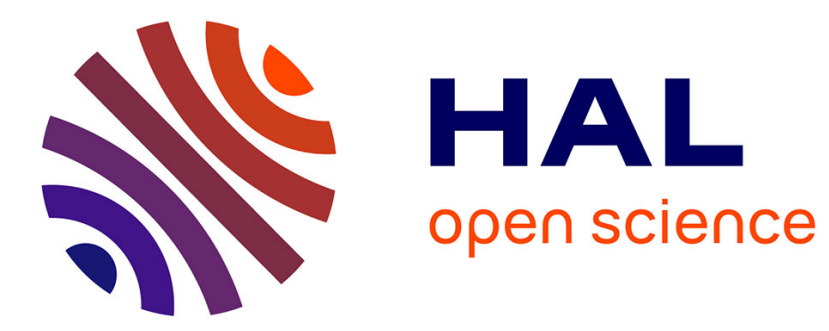

\title{
Intractable Nausea and Vomiting: Gut Is Not Always the Answer
}

Thomas Frapard, Zahir Amoura, Marc Pineton de Chambrun

\section{To cite this version:}

Thomas Frapard, Zahir Amoura, Marc Pineton de Chambrun. Intractable Nausea and Vomiting: Gut Is Not Always the Answer. The American Journal of Medicine, 2019, 132, pp.1419 - 1420. 10.1016/j.amjmed.2019.05.046 . hal-03488364

\section{HAL Id: hal-03488364 https://hal.science/hal-03488364}

Submitted on 21 Dec 2021

HAL is a multi-disciplinary open access archive for the deposit and dissemination of scientific research documents, whether they are published or not. The documents may come from teaching and research institutions in France or abroad, or from public or private research centers.
L'archive ouverte pluridisciplinaire HAL, est destinée au dépôt et à la diffusion de documents scientifiques de niveau recherche, publiés ou non, émanant des établissements d'enseignement et de recherche français ou étrangers, des laboratoires publics ou privés.

\section{다)(1) $(5$}

Distributed under a Creative Commons Attribution - NonCommercial| 4.0 International 
Intractable nausea and vomiting: gut is not always the answer.

\section{Authors:}

Thomas Frapard, $\mathrm{MD}^{1}$; Zahir Amoura, MD, $\mathrm{MSc}^{1}$; Marc Pineton de Chambrun, MD, MSc ${ }^{1,2}$

\section{${ }^{1}$ Sorbonne Université, Assistance Publique-Hôpitaux de Paris, Hôpital La Pitié-Salpêtrière, Institut}

E3M, Service de Médecine Interne 2, Centre de référence national Lupus Systémique et Syndrome des Anticorps Antiphospholipide, Paris, France.

${ }^{2}$ Sorbonne Université, Assistance Publique-Hôpitaux de Paris, Hôpital La Pitié-Salpêtrière, Institut de Cardiométabolisme et Nutrition, Service de Médecine Intensive-Réanimation, Paris, France.

Correspondence to : Marc Pineton de Chambrun, Service de Médecine Interne 2 et Service de

Médecine Intensive-Réanimation, Hôpital La Pitié-Salpêtrière, 47-83, boulevard de l'Hôpital, 75651

Paris Cedex, France; marc.pinetondechambrun@aphp.fr ; marc.dechambrun@gmail.com

Tel: +33 (0)1 848276 32, +33(0)142178301

\section{Conflict of interest: none}

Funding: none

Contributions: TF, ZA and MPdC contributed to manuscript redaction and correction

Article Type: Images in Radiology

Key words: area postrema syndrome; nausea; vomiting; Neuromyelitis Optica; Anti-aquaporin 4 autoantibodies

Running-head: A rare cause of intractable nausea and vomiting 


\section{PRESENTATION}

A 27-years-old female, with no medical history, was referred to the internal medicine department for intractable nausea, vomiting and hiccup. Symptoms had started one month prior and she had lost $13 \mathrm{~kg}$ of body weight meanwhile. She was complaining of headaches, photophobia and mild epigastric pain.

\section{ASSESSMENT}

She was afebrile, the physical examination was unremarkable, with a normal abdominal and neurological examination including the absence of neck stiffness. Nausea and vomiting were refractory to the association of metoclopramide, ondansetron and alizapride. There was no history of cannabis consumption. Standard laboratory tests were within the range of normal values, including negative $\beta$-HCG assay and unremarkable cerebrospinal fluid. Abdominal, cerebral CT-scan and gastroscopy were normal.

\section{DIAGNOSIS}

Cerebral MRI revealed T2 weighted (FLAIR) hyperintensity in the Area Postrema (Figure 1, white arrow). The ophthalmologic examination, as well as the MRI imaging of the spinal cord and the optic nerves were normal. Anti-aquaporin 4 autoantibodies (AQP4) were positive in the serum consistent with the diagnosis of Neuromyelitis Optica Spectrum Disorders (NMOSD) with isolated Area Postrema Syndrome.

\section{MANAGEMENT}

Symptoms swiftly resolved under high dose corticosteroids and azathioprine. Nausea and vomiting relapsed during corticosteroids tapering, requiring treatment intensification with plasmapheresis and rituximab. NMOSD are a group of central nervous system inflammatory autoimmune demyelinating diseases, mainly associated with a pathogenic autoantibody specific for the AQP4 water channel ${ }^{1}$. 
1 NMOSD-typical brain MRI lesions occur in AQP4-enriched areas including the Area Postrema, an

2 emetic reflex center at the floor of the fourth ventricle ${ }^{2}$. Area Postrema Syndrome can be the first or

3 the sole manifestation of NMOSD. Early detection of Area Postrema Syndrome is crucial as severe optic neuritis and/or transverse myelitis may occur. NMOSD are frequently refractory disease requiring aggressive management including corticosteroids, plasmapheresis and rituximab.

\section{REFERENCES}

1. Wingerchuk DM, Banwell B, Bennett JL, et al. International consensus diagnostic criteria for neuromyelitis optica spectrum disorders. Neurology 2015;85:177-189.

2. Shosha E, Dubey D, Palace J, et al. Area postrema syndrome: Frequency, criteria, and severity in AQP4-IgG-positive NMOSD. Neurology 2018;91:e1642-e1651. 
1 FIGURE LEGEND

2 Coronal, sagittal and axial FLAIR MR images demonstrate hyperintensity in the area 3 postrema (white arrows). 


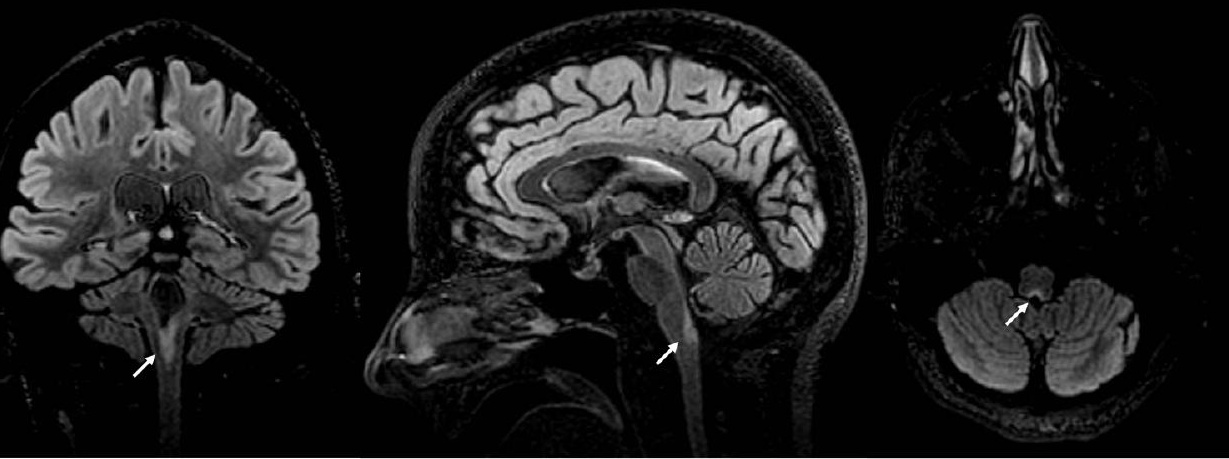

